\title{
Lessons from Dystopia: The Security of Nations and the Securitized Citizen
}

\author{
Liam Francis Gearon
}

\section{Contents}

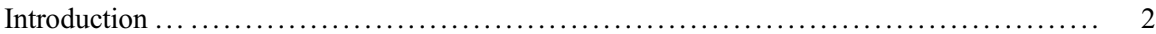

The Security of Nations and the Securitized Citizen ............................... 3

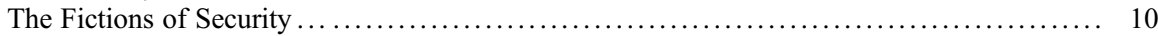

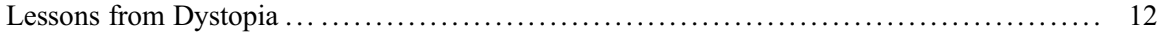

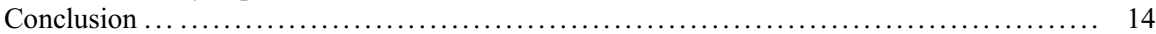

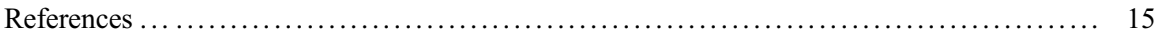

\section{Abstract}

This chapter provides a critical overview of the complex relationship between citizenship education and state security. Drawing on some major sources from the historical literature of totalitarianism, the chapter provides necessary reminders that these current concerns over security are far from new, but argues that bearing them constantly in mind is essential since citizenship education and the universal human rights values it espouses arose in the modern, post-Second World War era precisely as a response to the global trauma of autocracy, dictatorship, and totalitarianism. Critically demonstrating, though, that risk and threat to societal and geopolitical order - the security of nations - are transnational, it highlights the 2020 pandemic as a primary exemplar of such threat to the security of nations. Delineating this part of a now well-documented context of securitization, these new contexts do not easily fit, it is argued, traditional models of national citizenship education nor too optimistic models of global collaborative cosmopolitanism. In examining the present-day transnational notions of intensified threats as a reconfiguration of the traditional correlation of citizenship education and state security, the chapter argues for both a forward-looking urgency and a simultaneous turning not to political diktat but to the imaginative configurations of societal and geopolitical problematics. Taking dystopian literature as an

L. F. Gearon $(\bowtie)$

University of Oxford, Oxford, UK

e-mail: liam.gearon@education.ox.ac.uk

(C) The Author(s), under exclusive licence to Springer Nature Switzerland AG 2020 
exemplar, here, it is argued that amidst the fictionally threatened security of nations, the securitized citizen and the state itself may conjointly find both reflective freedom and creative solution to very real non-fiction problems. Such problematics are, however, it is argued, as existential as they are practical or political. These are the lessons from dystopia.

\section{Keywords}

Security $\cdot$ Citizenship $\cdot$ Dystopia $\cdot$ Pandemic $\cdot$ Camus

\section{Introduction}

This chapter provides a critical overview of the complex relationship between citizenship education and state security. It highlights a still relatively recent, post9/11 shift in the relationship between the citizen and the state. In this important context, citizenship education, understood in the broadest sense, has increasingly taken a role in the protection against the threats, real and imagined, posed by the global environment of terror. Here citizenship education is part of a wider, mandated, that is, legislatively integrated, role of education as a public policy measure in a general struggle against violent and ideological extremism. Drawing on some major sources from the historical literature of totalitarianism, the chapter provides necessary reminders that these current concerns over security are far from new, but argues that bearing them constantly in mind is essential since citizenship education and the universal human rights values it espouses arose in the modern, post-Second World War era precisely as a response to the global trauma of autocracy, dictatorship, and totalitarianism. The chapter critically demonstrates, though, that risk and threat to societal and geopolitical order - the security of nations - are transnational. Pandemic and environmental crisis are primary exemplars of such threat to the security of nations. This is part of a now well-documented context of securitization (Van Munster 2012). These new contexts do not easily fit, it is argued, traditional models of national citizenship education nor too optimistic models of global collaborative cosmopolitanism. In examining the present-day transnational notions of intensified threats as a reconfiguration of the traditional correlation of citizenship education and state security, the chapter argues for both a forward-looking urgency and a simultaneous turning not to political diktat but to the imaginative configurations of societal and geopolitical problematics. Taking dystopian literature as an exemplar, here, amidst the fictionally threatened security of nations, the securitized citizen and the state itself may conjointly find both reflective freedom and creative solution to very real non-fiction problems. Such problematics are, however, it is argued, as existential as they are practical or political. These are the lessons from dystopia. 


\section{The Security of Nations and the Securitized Citizen}

Terrorism has brought citizenship to the foreground of national political life in ways which are new but not unprecedented. It is evident in the number of ways in which counterterrorist measures traverse all aspects of public policy. While itself a highly contested term with multiple academic and legal definitions, many of which center around who is defining the terrorist act and the terrorist actor, in the power play of international legislation overseen by the United Nations, terrorism - along with a multitude of other transnational threats, the environment, and organized crime - is identified as one of the key areas of threat to international stability (UN 2019). With its "devastating human cost ... in terms of lives lost or permanently altered, terrorist acts aim to destabilize governments and undermine economic and social development," terrorism is characterized as posing "a major threat to international peace and security" which "undermines the core values of the United Nations." Responding to such threats to international stability, the United Nations' collective determination has been to create "a common universal legal framework against terrorism," this is one supported by instruments of the United Nations Security Council (UN 2019). The United Nations Security Council Counter-Terrorism Committee (CTC), guided by Security Council resolutions 1373 (2001) and 1624 (2005), was established "in the wake of the 11 September terrorist attacks in the United States" in order "to bolster the ability of United Nations Member States to prevent terrorist acts both within their borders and across regions." The consequent the Global CounterTerrorism Strategy consists of four pillars, which deeply integrate not only legal measures but historical and socio-geopolitical impetuses, security actions in directly countering violent ideology and action, and is supported, above all, by measures of reinforcement of the international community in the rule of law and human rights (UN 2019). Directly and indirectly, such measures have helped define the nature of the citizen in national life and the international community. If terrorism is seen as threatening of the world order, of stability, engendering conflict, under a variety of terms - ideological and violent extremism, radicalization - global moves to counterterrorism have become an integral part of a struggle to identify (or more properly reaffirm) the acceptable limits of social, cultural, and particular participation. Such developments have highlighted here, too, the role of education across all age phases in the formation of the citizen.

Exemplars illustrative of how these notions have impacted educational institutions include, in the UK, the Counter-Terrorism and Security Act 2015 and its legal definition of extremism as opposition to "fundamental British values" (CTSA 2015). For universities in particular the CTSA 2015 has brought major new legal responsibilities including the monitoring of and reporting on ideologies and actions deemed to be potentially a cause of terroristic incident (UUK 2016). Multiple ethical and professional issues are raised by such legislative developments, from academic integrity, freedom of speech, and the independence of academic institutions themselves, matters which I have charted extensively. The notions of British values are themselves contested both in definition and, by default, implementation in schools and universities. 
The domestic and foreign policy of the European Union now integrates similar security concerns of all aspects of its bureaucratic operations, making security an integral part of European social, cultural, and polity life (EAS 2015). Across Europe, and of course globally, religion has been a critical element in this process, and debates have raged now for several years about how justifiable is the increasing politicization and securitization of religion in education (Gearon 2019a). An important review of the global literature shows just how widespread are measures to counter ideological and violent extremism in education (Ghosh et al. 2016).

These developments are often seen, however, as part of a wider and deeper process of societal securitization. Some years before 9/11 the Copenhagen School thus determined that the shift of security policy away from its traditional home in military and related intelligence structures for national defense to the intrusion of security agendas into civil and public life, a move which has been labeled "securitization" (Albert and Buzan 2011; Buzan et al. 1997; Buzan and Hansen 2009; Laustsen and Wæver 2000; Taureck 2006). Raising the usual specter of a tension between liberty and security, such enhanced public policy moves to increase security provision have increasingly been challenged as problematic to the foundational values of Europe itself, particularly the 1950 European Convention on Human Rights and the plethora of rights legislation which came thereafter (Gearon 2016, 2019b; Gearon et al. 2019). The most systematic critique has come from arguably the world's leading human rights organization. Thus, Amnesty International's Report Dangerously disproportionate: The ever-expanding national security state in Europe, while recognizing the requirement of states to counter "wanton violence," this being "obvious and urgent," but highlights, too, that "the right to life, enabling people to live freely, to move freely, to think freely" are "essential tasks for any government." Amnesty argue, though, that security cannot trump liberty; the tasks of societal protection against risks to life in particular cannot be made justifications for nations "riding roughshod over the very rights that governments are purporting to uphold".

If terror has largely defined the geopolitics of the early twentieth-first, totalitarianism defined the twentieth (Friedrich and Brzezinski 1967). Long before the pervasive present-day lexicon of terror entered the politics of national and international governance, Hobsbawm had defined the twentieth century as "the age of extremes." Following the end of the Cold War, there had been an anticipation that the extremes witnessed in global politics would be ameliorated by a new world order, one characterized by the shared international trajectory toward liberal democracy, a move which marked by no less than "the end of history".

Arguably the last "end of history" had occurred at the close of the Second World War, the formal defeat of Fascism and Nazism, the foundation of the United Nations, and the instigation of a value code of universal human rights. The framing of the foundational document of the Universal Declaration of Human Rights by the United Nations on 10 December was a direction imitation of the eighteenth-century documents which defined the modern world through near parallel aspiration to the rights of the citizen which guided the revolutions in America and in France. The violence used to achieve these rights for the citizen always, in the eighteenth as in the 
mid-twentieth centuries, also presented contradictory moral problems. This is why a number of scholars - whose voices in my view are too little listened to today cautioned against the violent imposition of values and highlighted the ironic parallels between fraternity, freedom, and equality espoused and their actuality in history. Karl Popper's The Open Society and Its Enemies thus castigated the oppression that defined the historical realities of state communism inspired by Marx, but saw, too, the origins of the totalitarian in the classical era of Plato to which the anti-clerical revolutionaries, at least in France, drew so much of their inspiration. It is why Isaiah Berlin in his "Two Concepts of Liberty" stressed that freedom was something in name only when it was imposed by violence of either imposed ideologies and or the force of the state. It is why Hannah Arendt The Origins of Totalitarianism took the historical long view of the twentieth century and detailed the germinating ideas and power structures of modern dictatorship both in the western prevalence for colonialism and imperialism. These contradictions persisted even in what I am calling here the first modern "end of history" at the end of the Second World War. For a number of powerful Security Council signatories of the Universal Declaration of Human Rights remained at that time colonial powers, most notably Britain and France. The Security Council formed in San Francisco in June 1945 to oversee the new world order themselves sanctioned the American bombing of Hiroshima and Nagasaki a mere few weeks later in August 1945.

In what I term here the second "end of the history" at the end of the Cold War, the resentment of nations and interest groups at the imposition of values which they did not espouse, though their own states did, and which they even felt contradicted their own outlook on the world - what is fashionably today called a "worldview," itself an ideological imposition - provided the new basis for conflict. It was to be, as we know now, less a war of ideology than a conflict of cultures and especially those religious cultures rooted in histories millennia older than the United Nations.

The late Samuel Huntington, as I have highlighted in many other writings, himself predicted this and wrote an indirect retort to his former Harvard student in a work itself castigated for introducing the lexicon of conflict into a world that had just settled to a peaceful new era: The Clash of Civilizations (Gearon 2019a; Gearon et al. 2019). The tensions between the universality of human rights values and especially religious traditions are not uniform. There are multiple differences of accommodation and rejection to the United Nations' notions of rights, and even arguments that the secular formulations of these rights are themselves of religious or theological origin (Gearon 2016). Yet there is now a vast literature which interrogates the terrain.

In both eras, education has been and remains the most prominent point of public policy for the formation of citizens. It was ever thus. And there is arguably nothing surprising in political systems wish for and seeking models of education which uphold their political ideals. Both the totalitarianism of the twentieth century and the terror of the twenty-first - both versions of an extreme - are distinctive in the marriage of ideology and violence. For the state and state education systems, this has meant the need, in both cases, and universally the case today, to conjoin the security of the state through education for the formation of citizens. By which move, 
inevitably, the security of nations securitizes the citizen. The conjoining of these notions of national security and the securitized citizen is a fact of our age and a now near indelible feature of our educational institutions.

A large proportion of my recent work has been in examining these issues of security in the context of universities, and particularly important here has been an elaboration of models which deal with university relations with the security and intelligence agencies (Gearon 2019a, b, c, d). Here, I have conceptualized and provided the foundations for an academic subfield of education, security, and intelligence studies. As highlighted above, this has been critically prompted by the widening of security to areas beyond its traditional home in explicit military concerns. The disciplines of security and intelligence studies have themselves begun to respond to these wider notions of threat and in so doing have begun to refine the remit of their own fields (Gearon 2019a).

In terms of policy, research, and theoretical framing, this is what I have termed the universities-security-intelligence nexus. In essence this nexus is concerned with the elaboration of higher education institutions - in teaching, policy, and research - with state security apparatus in order to protect against risk and threat in the present and in preparedness for the future. Because learning from the past is critical to addressing both present and future concerns, the past histories of such questions are also significant, indeed foundational. There are few academic disciplines which do not fall into this remit. The universities-security-intelligence nexus has four overlapping domains: the operational, the epistemological, the ethical, and the existential. The operational defines the different modus operandi of engagement between universities and security and intelligence agencies and deals now significantly with threats which go beyond the nation state; the epistemological domain is concerned with knowledge and marks the shared interest of security and intelligence agencies in knowledge to deal with both national and transnational threat; the ethical domain treats of those multiple ranges of issues which such interactions being to different types of institutions in and through their collaboration, academic and securityoriented; the existential domain demonstrates a common shared set of highly complex concerns centered around forewarning or predicting of threat and measures such as civil contingency and emergency governmental powers enacted for the protection against such threats, which, again, now far transcend (and arguably put into perspective) national concerns about the protection of states, in large measure because we are now concerned as a human species not merely with the survival of states and societies but of species and the shared planetary environment (Gearon 2019a). The modeling can be presented as follows (Fig. 1).

Writing in the present-day midst of a still unfolding coronavirus pandemic is a tragic illustration of the urgency and indeed unpredictability of such nascent and future threat. All of which have brought in broadly conceived terms security to foreground of nation states. The role of universities in confronting and finding solutions to such threats is evident but also highlights a wider and deeper issue about the role of universities themselves in the formation of educated citizens able to learn and to research and thereby make a contribution to the well-being of societies through the formation of its citizens who in turn further contribute to the well-being 


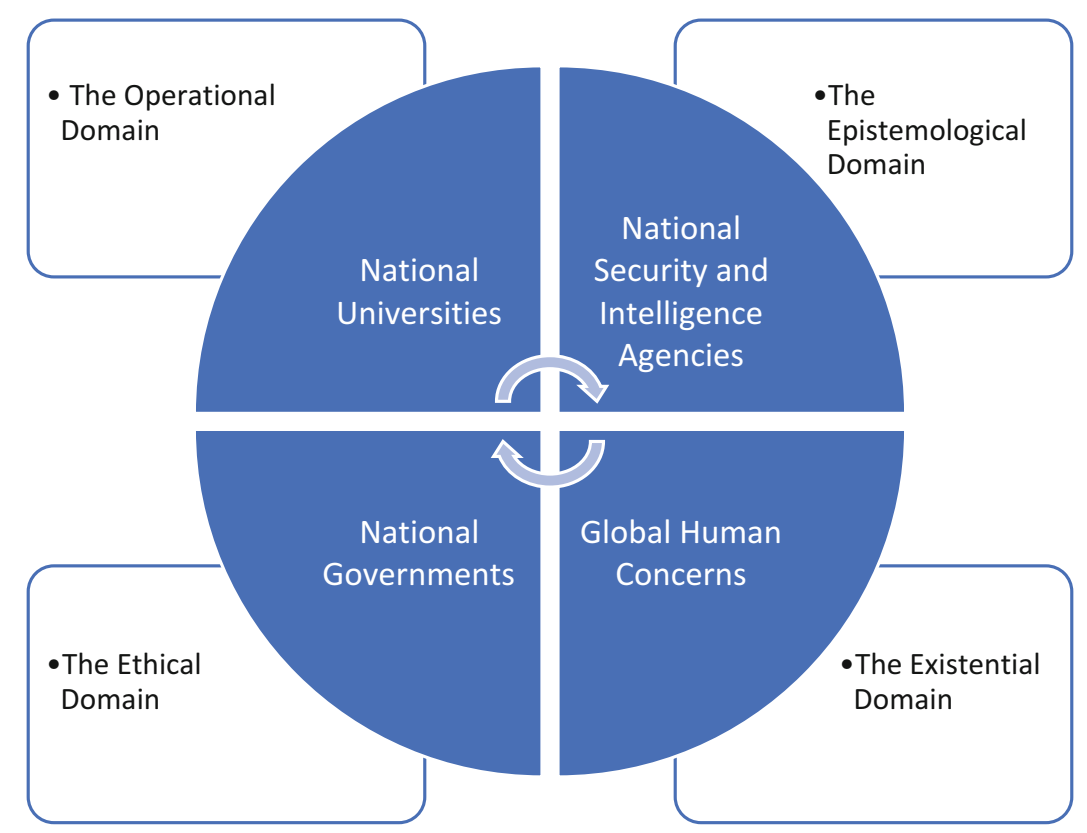

Fig. 1 The Universities-Security-Intelligence Nexus (Gearon 2019c)

of societies of which they are part (Dunn Cavelty and Balzacq 2017). Historical analyses of the social and political role of universities in the creation, dissemination, and application of knowledge - which today is most often conceptualized as "impact" - have in the west at least been an evolving part of the defining role of the university itself.

International public policy initiatives, importantly from the United Nations itself, have in recent years begun to frame these broader notions as a concern for citizens through the notion of "human security." For example, the UN's "Framework for Cooperation for the system-wide application of Human Security" (UN 2015) integrates and highlights the global community's needs for prediction and protection to address these pressing and complexly interrelated societal, that is, today, shared global problems:

For many people, today's world presents insecure threats on many fronts. Natural disasters, violent conflicts, persistent poverty, epidemics and economic downturns impose hardships and undercut prospects for peace and stability, as well as sustainable development. Crises are complex, entailing multiple forms of human insecurity. When they overlap, they can grow exponentially, spilling into all aspects of people's lives, destroying entire communities and crossing national borders. (UN 2019)

The United Nations Trust Fund for Human Security conceptualizes these around three freedoms, freedom from want, freedom from fear, and the freedom to live in dignity (UN 2019). In conceptual and theoretical terms, instances of such 


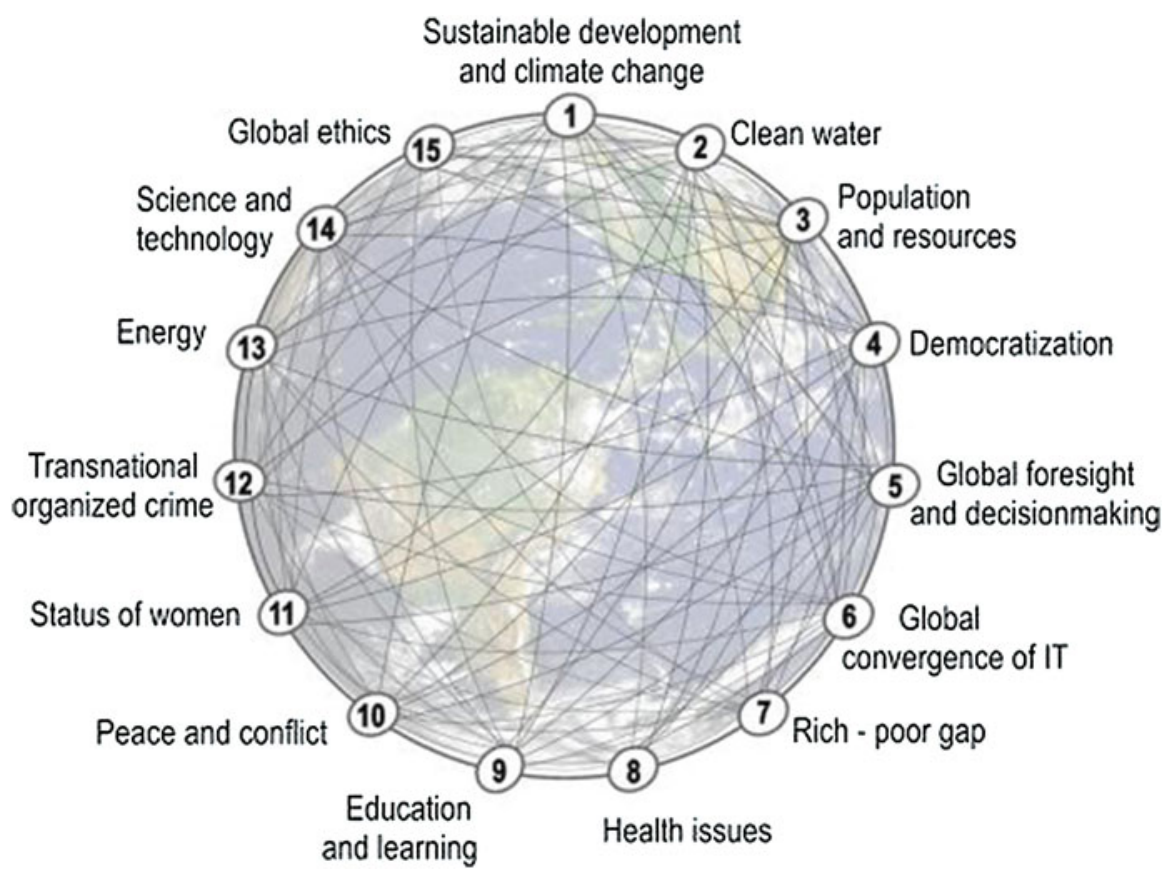

Fig. 2 Millennium Project, State of the Future Global Challenges

transnational preparedness in many senses coincide with securitization theory so presciently modeled by the Copenhagen School.

The role of education, and particularly higher education dimension, remains critical. Originally founded under the auspices the American Council for the United Nations University, the Millennium Project has thus, by way of example, for decades now produced State of the Future reports both as a reflection of current preoccupations of human societies and as a predictive set of measures to enable the prioritizing of protection against such problems. Here is a diagrammatic representation of one recent modeling (Fig. 2):

The UK security and intelligence themselves have, too, long expressed the need, in their rare public announcements, to broaden public understanding of societal threat and security against such. As a former Director General of MI5 remarked: “...progress has been made in reducing our national vulnerabilities - there have been definite improvements - but I worry that, against the background of no attacks here, we risk becoming complacent. So my message is to broaden your thinking about security issues". Speaking to a community of business representatives, even now nearly two decades ago, she said:

A narrow definition of corporate security including the threats of crime and fraud should be widened to include terrorism and the threat of electronic attack. In the same way that health 
and safety and compliance have become part of the business agenda, so should a broad understanding of security...

More recently the current Chief of the Secret Intelligence Service, MI5's sister agency MI5, Alex Younger, speaking at St Andrews University similarly stated:

Across the century of SIS's existence, we have evolved continuously to confront each generation of threat: from the World Wars to the Cold War to the rise of transnational threats including international terrorism. Now, we are evolving again to meet the threats of the hybrid age.

The notion of hybridity in warfare is important. If widening of security concerns to aspects of society previously untouched by it defines securitization theory, warfare itself has come into the foreground of society too. Thus, the post-Cold War era has seen the mergence of the notion of "hybrid," "hybrid threat," or "nonlinear" warfare, connoting "the use of conventional military force supported by irregular and cyber warfare tactics". The Russian determination of "nonlinear conflict" is a variant form of this now widely applied strategic term which in effect "has meant has meant major shifts in intelligence gathering and in the epistemological complexity of intelligence gathering., including the widening and deepening of dependencies on academic expertise, and far transcending traditional images of spy-craft and espionage". This is accepted as a fact of modern security now because "the sources of knowledge required to combat threat or perceived from sources beyond the conventionally military have inexorably multiplied." Ball usefully summarizes the distinctions:

\footnotetext{
Linear conflicts are defined by a sequential progression of a planned strategy by opposing sides, whereas nonlinear conflict is the simultaneous deployment of multiple, complementary military and non-military warfare tactics. A nonlinear war is fought when a state employs conventional and irregular military forces in conjunction with psychological, economic, political, and cyber assaults. Confusion and disorder ensue when weaponized information exacerbates the perception of insecurity in the populace as political, social, and cultural identities are pitted against one another.
}

I have analyzed at length how such a proliferation of conflict and security contexts has impacted educational institutions, those students who attend them, the academic who teach and research there, and the managers who oversee the objectives of universities and related institutions themselves.

Unarguably modern warfare itself has traversed the boundaries between military and civilian. The bombing of civilian populations in the Second World War is the prime modern example, including the bombing of Hiroshima and Nagasaki which formally defined its close. Security and intelligence agencies, too, have always been interested not simply in the military capacity of enemies but in their societal makeup, and indeed their own, to see traces of weaknesses in defense or in preparedness for attack. The Cold War is good instance, and John Preston's extensive work on government work on the civil preparedness of citizens in the event of a nuclear strike on them has been critical in developing our understanding of how the notion of 
securitized citizen is not new, only new formulated by the issues of another though not so far distant age. And as, too, an extensive literature show, the Cold War in particular was as keenly about culture as traditionally defined by the arts, literature, and ideological identity as it was about nuclear armaments.

\section{The Fictions of Security}

Fictional representations of such threats are rarely far from the spy agencies. Alex Younger - the same MI6 Chief who above showed the importance of a widening definition of security - only recently highlighted this in identifying his role with a famous fictional spy and distancing his professional work from another: "the merits of what he considered to be appropriate characters in fiction": "... I should make it clear that, despite bridling at the implication of a moral equivalence between us and our opponents that runs through novels, I'll take the quiet courage and integrity of George Smiley over the brash antics of 007, any day." There was, he claims, a further relevance to spy fiction:

We have attracted some great writers; some have become famous, many more have set aside their vocation and remained in the service. Some of the operational correspondence I have seen during my career would grace many an anthology were it not for its classification.

The relationship between the actual geopolitical of the secret world of spying and its fictional representation is even seen in symbiotic relationship:

\footnotetext{
Despite inevitable tensions between the secret and published world, the relationship has generally been of mutual benefit. Literature gains an edgy genre. We are painted in the minds of a global audience as some form of ubiquitous intelligence presence. This can be quite a force multiplier, even if it means we are blamed for an astonishing range of phenomena in which we have no involvement at all.
}

As Ewen MacAskill has argued, "It is a reminder, if ever one was needed, of how good fiction can question the way that governments work." As I have intimated elsewhere, there is good reason for this. If literature is a lie which seeks to tell a truth, and espionage is a trade dependent on deceit, where the two professions meet, the dissembling knows no limit (Gearon 2019a). John le Carré, writing of his real-world persona as novelist and former intelligence officer for both MI5 and MI6, sees a close, autobiographical, correlation between: "I'm a liar, born to lying, bred to it, trained to it by an industry that lies for a living, practised in it as a novelist". Spy fiction and spy facts have thus provided a range of novelistic practitioners who have drawn on their real-life experience as security and intelligence professionals prior to writing: Eric Ambler, John Bingham, John Buchan, Ian Fleming, Graham Greene, John le Carré, Eliza Manningham Buller, Somerset Maugham, and Arthur Ransome are instances of high renown and profile.

There is, though, a far wider correlation between the worlds of security and literature, a complex interface of cultural production of all varieties, and the security 
of nations and/or the ideologies which they represent, across all political hues (Chomsky 2008; Herman and Chomsky 1995; Wilkinson 2009). It is for this reason that literary as well as those who produce it have so often through history been targets of the regimes which their fictions are deemed to oppose. There are chilling examples from Nazi Germany, elaborated in sickening detail by Bytwek's (2004) Bending Spines. The large academic literature on propaganda shows how books and other cultural outputs have often become part of political and security apparatus of the state, something which in broader political terms has long fascinated modern cultural theory (Adorno et al. 2007). Interconnecting books and bombshells, Taylor (2003) thus calls propaganda the "munitions of the mind" (see also Taylor 1999, 2012). O'Shaughnessy (2000) defines propaganda as a "weapon of mass seduction" (also O'Shaughnessy 2016, 2017). And the use of often covert cultural influence is far from simply the provenance of the totalitarians. As a controversial and contested academic literature shows, liberal western societies have seen over decades a welldocumented series of interventions by security and intelligence agencies directly into the world of cultural influence (Miller Harris 2016; Risso 2014; Stonor Saunders 2013; Whitney 2018; Wilford 2003, 2009).

As I have shown, this also long predates the Second World War or the Cold War, but can be seen explicitly in the efforts of Britain's First World War Propaganda Bureau (Gearon 2019a). In the same early twentieth century, one author can even lay credit for having influenced the formation of Britain's Security Service and its Secret Intelligence Service. Chris Andrew, official biographer of MI5 even opens his Defence of the Realm with an introduction relating the importance of William Le Queux's 1906 story of German foreign invaders - in its time the massively bestselling The Invasion of 1910 - with the enhancement of a sense of British public insecurity, one which led, if indirectly to the early, formal establishment of the Britain's security and intelligence agencies (Andrew 2010).

In a context where citizen education and all the security agenda with which it has been faced in recent decades is so often delivered through lessons about the positive roles of democratic, human rights and government - very much rooted in the real world of actual, national, and international politics, and reported as such in the extensive literature of citizenship education research - literature here seems a less than well-used avenue for convening many of the themes which confront the subject. In terms of threat, risk, and imagined scenarios for dealing with the security of nations, spy literature is naturally important, as has been highlighted. It takes us, however, only so far. It rarely moves beyond representation of specific risks and their resolution to broader conceptualization of society's political future or indeed the planet's. What is now commonly framed in literary studies as dystopian fiction does so, and presents, I argue, some lessons which can enrich our perspectives both of the security of nations and the securitized citizen. I loosely term this approach lessons from dystopia. 


\section{Lessons from Dystopia}

The notion of "lessons from dystopia" originated as one element of a larger conceptualization to reconfigure the relationship between philosophy, literature, and education, with my own interests here focusing on political philosophy and questions of the security uses of literature in real-world socio-political contexts.

Originating from a symposium I convened at the Philosophy of Education Society of Great Britain (PESGB) at New College Oxford in 2013, developed through a major grant funded by PESGB for a seminar series on this theme, a Society for Educational Studies funded Colloquium on Writers and their Education at Oriel College Oxford (Gearon and Williams 2018), all culminated in two significant edited collections for international educational research journals (Gearon and Williams 2018, 2019). With a particular focus on citizenship education, the explicit notion of "lessons from dystopia" was the heading for a focus on the political dimensions of the interface of philosophy, literature, and education in 2016 at the British Academy, London. Borrowing from the seminar series theme, Christine Sypnowich's (2019) “Lessons from Dystopia: Critique, Hope and Political Education" - in our special issue of the Journal of Philosophy of Education - analyzed utopian and dystopian literature as an aspect of political education, detailing how the notion of utopia and dystopia appear both in literature and political philosophy. For the politically educative role of this "genre," she treated of Orwell's Nineteen EightyFour and Zamyatin's We. Beyond the broad sense of the political, I have undertaken extensive subsequent work on the relationship between security and literature (Gearon 2019a) and am currently also editing a Polish international journal, Text Matters, on the theme of Literature and Security.

In our Special Issue of the British Journal of Educational Studies on Writers and their Education (Gearon and Williams 2019) was included my article "Engineers of the Human Soul: Readers, Writers, and their Political Education" (Gearon 2019a). This detailed the long history and particularly acute modern history around the political uses and abuses of literature. I had framed my premise for discussion around an extreme example of the political uses of literature by highlighting Stalin's much quoted diktat presented to the firs congress of the Union of Soviet Writers that artists should be "engineers of the human soul," showing the uses to use cultural outputs, and especially literature had been used by dictatorial regimes as a means of upholding and furthering totalitarian goals, not least too in Hitler and Maoist regimes. Here I was particularly struck by recent attempts to construct "literature pedagogy" for cosmopolitan, "globalizing," political ends, specifically an article in the Harvard Education Review by Suzanne Choo (2017). These are and remain naturally more benign aims and purposes for the use of literature in schools, and of course in university literary studies, but my sense of wariness arose from the warnings of history about other more malign uses. My own piece provided some stark reminders about conjoining educational and political objectives through a literature not designed for either purpose. This has prompted a further recent response for Choo (2020), and the debate on the uses for specific goals in citizenship education is ongoing. And while there are difference of nuanced opinion - for 
example, between Choo and myself - on this pedagogic maneuvering of a literarypolitical aesthetic, the epistemological terrain is important, not least because the issues at stake are existential, that is, in fiction as in geopolitical factuality life and death at stakes, and not simply the life and death of individuals, but the life and death of societies and, indeed, that of the human species itself.

Cultural outputs and still here literature are important even in a digital age. There is narrative and counter-narrative in the political domain, and there is the narrative of fiction which it is often now claimed colors both (Croft and Moore 2010; Glazzard 2017), what Jameson (2002) famously called the political unconscious. Knowledgegathering by the security and intelligence agencies in new security contexts still includes focus on the representation of geopolitical realities, and the importance of this is evidenced in the prevalence of such terms as "fake news" and epistemological and political consideration of "post-truth." Fiction like security and intelligence gathering here are united in many ways by imagining unimaginable risks and threats. Environmental catastrophe; global health threats; attacks of global reach of a chemical, bacteriological, radiological, or nuclear nature; or future wars over the physical resources for survival (food and water and fuel) as much as physical territory are all equally integral features of new security landscapes. But they have been features of fictional landscapes for longer. It is not for no reason that the genre of science fiction, which has been critical in defining much modern utopian literature, emerged in the modern world contemporaneously with the rise of science, whether this is romantic rebellions and later science fiction reflection over the dehumanizing prospects of science and technology - from Frankenstein to Isaac Asimov's I, Robot series - or the fear of invasion. On the latter is a powerful instance of how fantastical variants on the latter theme in H. G. Wells' late nineteenth century War of the Worlds - Martians invade England - arguably impacted the more prosaic threat from across the Channel with, less than a decade later, William Le Queux's bestselling novel from 1906 The Invasion of 1910 which with journalist realism narrated a German military takeover of Britain. In all literary and political cases, the civilian, the citizen, all civilians, and all citizens are impacted. This extension of security to a wider population is not exclusive to the modern age, but it has in this era taken on particular forms.

Despite, then, particular reservations about the direct and heavy-handed uses of literature for political ends - even George Orwell is explicit about the political purposes of both his journalism and his fiction - or perhaps highlighted by them, literature remains one of the most powerful weapons in the arsenal of political education. Gregory Claeys' (2018) Dystopia: A Natural History provides powerful testimony here. Claeys' study of modern despotism, identifying its antecedents in political and religious history, its articulation in the West at least Christian theology and classical philosophy. In considerable detail - from Thomas More's sixteenthcentury Utopia to the classics of twentieth-century literature (focusing on George Orwell's Nineteen Eighty-Four and Aldous Huxley's Brave New World as iconic texts of a wider literature bordering science fiction and prophetic futuristic fiction) he shows how these political and theological themes of great antiquity continue to have their literary diffractions suited to the modern age through new genres of fiction. 


\section{Conclusion}

Within weeks of the coronavirus or COVID-19 outbreak, one of the perhaps not too surprising literary outcomes in the world of book sales has been the return of the Nobel Prize winning Albert Camus' 1947 classic set in the 1940s Oran, The Plague. I took from my own bookshelf at Oxford a 40-year-old edition of the novel read and dutifully underlined throughout, from my undergraduate study of philosophy and literature at the University of Lancaster. These personal biographical details are to me are important, as citizenship education tends so much toward the impersonal, the statistical, and the macro-political, leaving the individual voice as a sometimes less significant element in the broad sweep of geopolitical history. The writer, Camus, is here no exception, always draws on the personal, the world of character and characters, to show the individual, lived response to predicaments. Camus thus drew largely from his own Algerian-French heritage to write a story about a nondescript town in his homeland. The town, his narrator notes on the first page of The Plague, "let us admit, is ugly. It has a smug, placid air and you need time to discover what it is that makes it different from so many human business centres in other parts of the world." It is the particularities of Oran in confronting the plague, how its populace responds, and how the characters react. The devoted Dr. Bernard Rieux ministers to the sick and the dying, the Jesuit priest Father Paneloux ("very highly thought of in our town, even in circles quite indifferent to religion") to their souls, the police inspector who oversees order between the living and the dead, who visits and castigates the would-be suicide Cottard, the individuals who provide factual details our narrator has not directly observed - the journalist Raymond Rambert, or the journal-writer Jean Tarrou, and Joseph Grand, whose day job was as clerk at the Municipal Office and becomes responsible for charting the grim statistics of fatality, but whose private work was the more ambitious and lofty goal of studying "the growth of personality." The life and legacy of Camus endures, then, and one of the obvious facts of this legacy is the particular endurance of his literary as opposed to his more formally philosophical works. It success lies arguably in the multi-layered readings to which The Plague - like much great literature (greatness being measured in the extent not to which it sells on publication but the extent to which it sells beyond the author's own lifetime) - can be subject. Here, from excerpt taken from Olivier Todd's (1997) unsurpassed biography, is Camus, modestly declaiming his own genius, while outlining the multivalent readings of his own, even then famous, work:

La Peste may be read in three different ways. It is at the same time a tale about an epidemic, a symbol of Nazi occupation (and incidentally the prefiguration of any totalitarian regime, no matter where), and, thirdly, the concrete illustration of a metaphysical problem, that of evil ... which is what Melville tried to do with Moby Dick, with genius added (Camus, cited in Todd 1997: 168)

The novel as a literary form has in many respects thus its most profound impacts as literature by contrast with the personal reading, the imagining of oneself in 
situations unknown and untrammeled. It is one of the purposes of imaginative fiction not merely to transport the reader to other worlds but to enable to provide fresh readings of their own.

One of my challenges to Choo is in the providing of literature with a singular, however, beneficent reading, for broad political or narrow citizenship education purposes. In the context of the present challenges - and there are always present challenges - for the security of nations, the securitized citizen can choose either docilely to comply to the political diktat of the age or to venture forward into the less certain territory of moral and political ambiguity. One of the lessons here of dystopian fiction is something almost entirely neglected by citizenship education itself.

That is, in its original struggles to move from the metaphysical and the theological, the religious, and the existential, by focusing on the pressing realities let us say of the political pavement it neglected, and still does neglect, the heavens above. I do not think this was the intention of the Enlightenment context which did so much intellectually to frame the political movements of the eighteenth century, which is our political legacy today in liberalism, democracy, and human rights. Without doubt one of the founding figures of the Enlightenment, Immanuel Kant after all opened his 1788 Critique of Practical Reason (1788), his important thesis on the morality, by stressing the practicalities needed in the political and the social (the clue is in Kant's title), but never forgetting the cosmological and thus existential context which frame the former, and so important was this dual view for Kant that he frames his second Critique around it: "Two things fill the mind with ever new and increasing admiration and awe, the more often and steadily we reflect upon them: the starry heavens above me and the moral law within me." Indeed, so important were these sentiments on the existential that on his death Kant's friends chose these words for the epigram on the great philosopher's tombstone.

One of the lessons from dystopia is arguably then not the simple taking of practical political messages for the education of mechanistic citizens, cogs in the machinations of global politics, the taking of moral messages from books (though these may be drawn), but of using books to free citizens from, to enable them to see beyond, the narrowly conceived confines of the political to the personal, with some glimpse, however perplexing, of what ultimately remains the mystery of human existence.

\section{References}

Adorno, T. W., Benjamin, W., Bloch, E., Brecht, B., \& Lukacs, G. (2007). Aesthetics and politics. London: Verso.

Albert, M., \& Buzan, B. (2011). Securitization, sectors and functional differentiation. Security Dialogue, 42(4-5), 413-425.

Andrew, C. (2010). The defence of the realm: The authorized history of MI5. London: Penguin.

Bagge Laustsen, C., \& Wæver, O. (2000). In defence of religion: Sacred referent objects for securitization. Millennium, 29(3), 705-739. 
Buzan, B., \& Hansen, L. (2009). The evolution of International Security Studies. Cambridge: Cambridge University Press.

Buzan, B., Waever, O., \& de Wilde, J. (1997). Security: A new framework for analysis. Boulder: Lynne Rienner.

Bytwek, R. L. (2004). Bending spines: The propagandas of Nazi Germany and the German Democratic Republic. East Lansing: Michigan State University Press.

Chomsky, N. (2008). Media control: The spectacular achievements of propaganda. New York: Seven Stories Press.

Choo, S. (2017). Globalizing literature pedagogy: Applying cosmopolitan ethical criticism to the teaching of literature. Harvard Educational Review, 87(3), 335-356.

Choo, S. (2020). Expanding the imagination: Mediating the aesthetic-political divide through the third space of ethics in literature education, British Journal of Educational Studies. https://doi. org/10.1080/00071005.2020.1735298. Published online 1 March 2020. Retrieved 14 March.

Claeys, G. (2018). Dystopia: A natural history. Oxford: Blackwell.

Croft, S., \& Moore, C. (2010). The evolution of threat narratives in the age of terror: Understanding terrorist threats in Britain. International Affairs, 86(4), 821-835.

CTSA. (2015). Counter terrorism and security act. London: HM Government. Retrieved March 14, 2020, from http://www.legislation.gov.uk/ukpga/2015/6/contents/enacted

Dunn Cavelty, M., \& Balzacq, T. (Eds.). (2017). The Routledge handbook of security studies. London: Routledge.

EAS. (2015). European agenda on security. Brussels: European Commission. Retrieved March 14, 2020, from https://ec.europa.eu/home-affairs/what-we-do/policies/european-agenda security_en

Friedrich, C. J., \& Brzezinski, S. (1967). Totalitarian dictatorship and autocracy. New York: Praeger.

Gearon, L. (2016). Global human rights. In A. Peterson, R. Hattam, M. Zembylas, \& J. Arthur (Eds.), The Palgrave international handbook of education for citizenship and social justice (pp. 205-228). London: Palgrave Macmillan.

Gearon, L. (2019a). The politicisation and securitisation of religion in education: A response to a rejoinder. In M. L. Pirner, J. Lahnemann, W. Haussmann, \& S. Schwarz (Eds.), Public theology perspectives on religion and education (Routledge research in religion and education) (pp. 211227). New York: Routledge.

Gearon, L. (2019b). Human rights RIP: Critique and possibilities for human rights literacies. In C. Roux \& A. Becker (Eds.), Human rights literacies: Future directions. New York: Springer.

Gearon, L. (2019c). The universities-security-intelligence nexus. In The Routledge international handbook of universities, security and intelligence studies. London/New York: Routledge.

Gearon, L. (2019d). A landscape of lies in the land of letters: The literary cartography of security and intelligence. In The Routledge international handbook of universities, security and intelligence studies. London/New York: Routledge.

Gearon, L., \& Williams, E. (Guest Eds.). (2018). Philosophy, literature and education (special issue). Journal of Philosophy of Education, 52(4), 577-777.

Gearon, L., \& Williams, E. (Guest Eds.). (2019). Writers and their education (special issue). British Journal of Educational Studies, 67(3), 283-289.

Gearon, L., Kuusisto, A., \& Musaio, M. (2019). The origins and ends of human rights education: Enduring problematics, 1948-2018. In L. Di Donato \& E. Grimi (Eds.), Metaphysics of human rights1948-2018. On the occasion of the 70th anniversary of the UDHR. New York: Vernon Press.

Ghosh, R., Manuel, A., Chan, W. Y. A., Dilimulati, M., \& Babaei, M. (2016). Education and security: A global literature review on the role of education in countering violent religious extremism. Tony Blair Institute for Global Change. Retrieved March 14, 2020, from https:// institute.global/sites/default/files/inline-files/IGC_Education\%20and\%20Security.pdf

Glazzard, A. (2017). Losing the plot: Narrative, counter-narrative and violent extremism. The International Centre for Counter-Terrorism - The Hague, 8(8). https://doi.org/10.19165/2017.1.08.

Herman, E. S., \& Chomsky, N. (1995). Manufacturing consent: The political economy of the mass media. London: Vintage. 
Kant, I. (1788). Critique of practical reason (trans: Abbott, T.K.). London: Longmans, Green and Company. Retrieved March 14, 2020, from www2.hn.psu.edu/faculty/jmanis/kant/critique-prac tical-reason.pdf

Miller Harris, S. (2016). The CIA and the Congress for cultural freedom in the early Cold War. London: Routledge.

O'Shaughnessy, N. J. (2000). Politics and propaganda weapons of mass seduction. Manchester: Manchester University Press.

O'Shaughnessy, N. J. (2016). Selling Hitler: Propaganda and the Nazi brand. London: C. Hurst \&.

O'Shaughnessy, N. J. (2017). Marketing the Third Reich. London: Routledge.

Risso, L. (2014). Propaganda and intelligence in the Cold War: The NATO information service. London: Routledge.

Stonor Saunders, F. (2013). The cultural Cold War: The CIA and the world of arts and letters. New York: The New Press.

Sypnowich, C. (2019). Lessons from dystopia: Critique, hope and political education. Journal of Philosophy of Education, 52(4), 660-676.

Taureck, R. (2006). Securitization theory and securitization studies. Journal of International Relations and Development, 9, 53-61.

Taylor, P. M. (1999). British propaganda in the 20th century. Edinburgh: Edinburgh University Press.

Taylor, P. M. (2003). Munitions of the mind: A history of propaganda from the ancient world to the present era. Manchester: Manchester University Press.

Taylor, F. (2012). Exorcising Hitler: The occupation and denazification of Germany. London: Bloomsbury.

Todd, O. (1997). Albert Camus: A life. London: Vintage.

UN. (2015). Framework for cooperation for the system-wide application of human security. Retrieved March 14, 2020, from https://www.un.org/humansecurity/wpcontent/uploads/2017/ 10/Framework-for-Cooperation-for-the-System-wide-Application-of Human-Security.pdf

UN. (2019). Transnational threats. Geneva: United Nations. Retrieved March 14, 2020, from https://www.un.org/ruleoflaw/thematic-areas/transnational-threats/

UUK. (2016). Universities and counter-terrorism. London: Universities UK.

Van Munster, R. (2012). Securitization. Oxford Bibliographies. Retrieved March 14, 2020, from http://www.oxfordbibliographies.com/view/document/obo $9780199743292 /$ obo978019974329 2-0091.xml

Whitney, J. (2018). Finks: How the C.I.A. tricked the world's best writers. Berkeley: OR Press.

Wilford, H. (2003). Calling the tune? The CIA, the British left and the Cold War. London: Frank Cass.

Wilford, H. (2009). The mighty Wurlitzer: How the CIA played America. Cambridge, MA: Harvard University Press.

Wilkinson, N. (2009). Secrecy and the media: The official history of the United Kingdom 's D-notice system. London: Routledge. 